\title{
YARI PARLAMENTER SİSTEM AYRI BİR HÜKÜMET SISTEMİ MODELİ OLABİLİR Mİ?
}

\author{
İsmail YAZICIOĞLU*
}

\section{$\ddot{O} Z$}

Bu çalışmada Steffen Ganghof tarafindan ortaya atılan yarl parlamenter sistem incelenmekte ve yart parlamenter sistemin ayr bir hükümet sistemi modeli olup olmadiğl sorusuna cevap aranmaktadır. Ganghof'un yarl parlamenter sistemi, yarl başkanlık sisteminden esinlenerek ancak bu sistemin tersi bir mantıkla oluşturduğu görülmektedir. Yarı başkanlık sisteminde, ikili yapıya sahip olan yürütme organının yalnızca bir bölümü (hükümet), görevine devam edebilmek bakımından yasama organının güvenine bağlıdır. Yarı parlamenter sistemde ise yasama organının iki bölüme sahip olması gerekmekte ve yürütme organının (hükümetin) görevine devam edebilmesi, yasama organının yalnızca bir bölümünün güvenine bağlı olmaktadır. Ganghof yarı parlamenter sistemi, yasama organının iki bölümlü olması üzerine kurmakta ve sistemin tanımlayıc unsurlarını ortaya koyarak, ideal bir yarl parlamenter sistem tasarlamaktadır. Bu unsurlar incelendiğinde, yarl parlamenter sistemin ayrı bir hükümet sistemi modeli olmadı̆̆g, parlamenter sistem kapsamında ve parlamenter sistemin alt bir türü olarak değerlendirilmesi gerektiği sonucuna ulaşılmaktadır.

Anahtar Kelimeler: Yart parlamenter sistem, Steffen Ganghof, hükümet sistemleri, iki meclislilik, üst meclis.

\section{CAN THE SEMI-PARLIAMENTARY SYSTEM BE A SEPARATE MODEL OF GOVERNMENT SYSTEM?}

\section{ABSTRACT}

In this paper, the semi-parliamentary system put forward by Steffen Ganghof is examined and an answer is sought to the question of whether the semi-parliamentary system is a separate model of government system. It is seen that Ganghof's semiparliamentary system is inspired by the semi-presidential system, but with the opposite logic of this system. In the semi-presidential system, only a part of the executive (government), which has a dual structure, depends on the legislature's trust in order to continue its office. In the semi-parliamentary system, the legislature must have

* Dr. Öğr. Üyesi, Ankara Sosyal Bilimler Üniversitesi Hukuk Fakültesi Anayasa Hukuku Anabilim Dali/ ANKARA, e-posta: i.yazicioglu@hotmail.com

ORCID : 0000-0003-0937-4941

DOI : 10.34246/ahbvuhfd.933624

Yayın Kuruluna Ulaştığı Tarih :20/11/2020

Yayınlanmasının Uygun Görüldüğü Tarih: 22/04/2021 
two parts and the executive (government) can continue to function, depending on the trust of only one part of the legislature. Ganghof bases the semi-parliamentary system on the two-part legislative body and designs an ideal semi-parliamentary system by revealing the defining elements of the system. When these elements are examined, it is concluded that the semi-parliamentary system is not a separate government system model, but should be considered within the extent of the parliamentary system and as a subtype of the parliamentary system.

Keywords: Semi-parliamentary system, Steffen Ganghof, government systems, bicameralism, upper house.

\section{GİRIŞ}

Hükümet sistemlerinin sinıflandırılmasında yasama ile yürütme organı arasındaki ilişkiler esas alınmakta, iki organ arasındaki ilişkilerin nasıl kurulduğu ise bazı kriterlere göre belirlenmektedir. Bu kriterlerle ilgili doktrinde görüş birliği bulunmamaktadır. Ancak hükümet sistemleri sınıflandırılırken, yasama ile yürütme organı arasındaki ilişkilerin genellikle yürütme organının kaynağı yani nasıl seçildiği (origin) ve göreve nasıl devam ettiği (survival) kriterlerine göre belirlendiği görülmektedir ${ }^{1}$. Bu kriterler, yalnızca yürütme organıyla ilgili gibi görünse de yasama organı dikkate alınarak açıklanmaktadır. Diğer bir deyişle, yürütme organının oluşumunda ve görevini devam ettirmesinde, yasama organı ile bir bağlantı kurulup kurulmamasına göre iki organ arasındaki ilişkiler biçimlenmektedir. Bunun sonucunda saf (pure) haliyle düşünüldüğünde bir tarafta parlamenter, diğer tarafta başkanlık sisteminin yer aldığı iki zıt kutup ortaya çıkmaktadır². Saf bir

\footnotetext{
Matthew Soberg Shugart/ John M. Carey, Presidents and Assemblies; Constitutional Design and Electoral Dynamics, Cambridge University Press, 1992, s. 19 vd.; Robert Elgie, "The Classification of Democratic Regime Types: Conceptual Ambiguity and Contestable Assumptions", 1998, 33(2), European Journal of Political Research, s. 221; David J. Samuels/ Matthew S. Shugart, Presidents, Parties, and Prime Ministers; How the Separation of Powers Affects Party Organization and Behavior, Cambridge University Press, 2010, s. 26-27; Arend Lijphart, "Introduction", in Arend Lijphart (Ed.), Parliamentary versus Presidential Government, Oxford University Press, 1992, s. 5-6.

2 Hükümet sistemlerini parlamenter sistem ve başkanlık sistemi şeklinde ikili bir ayrıma giderek sinıflandıran yazarlar da bulunmaktadır. Bununla ilgili bkz. Fred W. Riggs, "The Survival of Presidentialism in America: Paraconstitutional Practice", 1988, 9(4), International Political Science Review, s. 252.
} 
parlamenter sistemde yürütme organı, yasama organına bağımlıyken; saf bir başkanlık sisteminde yasama organından ayrılmaktadır³.

Hükümet sistemlerinin sınıflandırılmasında doğrudan yürütme organını ilgilendiren bazı kriterler de kullanılabilmektedir. $\mathrm{Bu}$ anlamda yapılan sınıflandırmalarda yürütme organının yetkilerine ${ }^{4}$ ve yapısına ${ }^{5}$ yani yürütme organının tekli (single) veya ikili (dual) olmasına yer verilebilmektedir. $\mathrm{Bu}$ kriterler daha çok, saf hükümet sistemi modelleri ile saf olmayan, karma özellik gösteren hükümet sistemi modellerinin birbirlerinden ayrılmasında önem taşımaktadır. Örneğin, karma bir hükümet sistemi modeli olan yarı başkanlık sisteminde yürütme organı ikili yapıya sahiptir. Yürütmenin bir tarafinda yer alan hükümet, yasama organı çoğunluğuna bağımlıyken; diğer tarafinda yer alan devlet başkanı halk tarafindan seçilmektedir. Ayrıca devlet başkanının önemli yetkilere sahip olması gerekmektedir ${ }^{6}$.

$\mathrm{Bu}$ çalışmanın konusunu ise Steffen Ganghof tarafindan ortaya atılan ve yarı başkanlık sistemi gibi karma bir hükümet sistemi modeli olduğu ifade edilen yarı parlamenter sistem oluşturmaktadır. Ganghof'a göre, yasama organı eşit meşruluğa sahip iki bölüme ayrillyor ve bu bölümlerden biri başbakan ve hükümetin görevine güvensizlik oyuyla son verebiliyorsa ayrı bir hükümet sistemi modelinden bahsedilir ${ }^{7}$. Yarı parlamenter şeklinde adlandırılan bu hükümet sistemi modelinin günümüzde Avustralya ve Japonya'da uygulandığ1 Ganghof tarafindan belirtilmektedir ${ }^{8}$. Yarı parlamenter sistem, yasama organı esas alarak tasarlanması bakımından dikkat çekmektedir. Zira yarı parlamenter sistemde, yasama ile yürütme organı arasındaki ilişkiler, yasama organının ikili yapıya (iki bölüme) sahip olması ve güvensizlik oyu verme yetkisinin yasama organının yalnızca bir bölümüne tanınması üzerine kuruludur. $\mathrm{Bu}$ çalışmada, hükümet sistemlerinin sınıflandırılmasında çok yaygın olmayan bu yaklaşım üzerine kurulmuş yarı parlamenter sistem, diğer hükümet sistemi

\footnotetext{
Samuels/ Shugart, s. 27.

4 Elgie, s. 221.

5 Lijphart, s.6.

6 Maurice Duverger, “A New Political System Model: Semi-Presidential Government”, 1980, 8(2), European Journal of Political Research, s. 166.

7 Steffen Ganghof, “A New Political System Model: Semi-Parliamentary Government”, 2018, 57(2), European Journal of Political Research, s. 261.

8 Ganghof çalışmasında, federal bir yapıya sahip Avustralya'nın New South Wales, Victoria, Tasmania, South Australia ve Western Australia eyaletlerinin de yarı parlamenter sistemin özelliklerini taşıdığını kabul etmektedir. Bkz. Ganghof, s. 261, 265 vd.
} 
modelleriyle karşılaştırılarak açıklanmakta ve yarı parlamenter sistemin ayrı bir hükümet sistemi modeli olup olmadığı sorusuna cevap aranmaktadır.

\section{YARI PARLAMENTER KAVRAMININ ORTAYA ÇIKIŞI VE GANGHOF'TAN ÖNCE DOKTRIINDEKİ YERİ}

Yarı parlamenter (semi-parliamentary) ifadesi, kavramsal açıdan ilk bakışta yarı başkanlık (semi-presidential) ifadesini çağrıştırmaktadır. Zira "yarı" (semi) kelimesinin, başkanlık sistemi- parlamenter sistem ikiliğinde, yarı başkanlık şeklinde kurumsallaşarak ayrı bir hükümet sistemi modeli oluşturması daha önce gerçekleşmiştir. Yarı başkanlık sistemini kurumsallaştıran Duverger, bu sistemin başkanlık sistemi ile parlamenter sistem arasında olduğunu ifade etmektedir'. Dolayısıyla Duverger'e göre "yarı" kelimesi "arada", "ortada" anlamını vermektedir. Bu duruma karşı çıkan Lijphart, yarı başkanlık sisteminin parlamenter sistem ile başkanlık sistemi arasında orta bir kategori olmadığını belirtmektedir. Lijphart'a göre yarı başkanlık sisteminde, devlet başkanının yasama organının çoğunluğuna hakim olup olmamasına göre başkanlık sistemi ve parlamenter sistem şeklinde değişimli bir görüntü ortaya çıkmaktadır ${ }^{10}$. Uluşahin ise Duverger' in görüşlerini değerlendirerek, yarı başkanlık sisteminin zaman içinde Duverger'in zihninde başkanlık sistemine daha da yaklaştı̆̆ını tespit etmektedir ${ }^{11}$.

Yarı başkanlık sisteminin ayrı bir hükümet sistemi modeli oluşturması bir kenara bırakıldığında, bu görüşlerden hareketle yarı parlamenter kavramının ortaya çıkışı ile ilgili de bazı değerlendirmeler yapılabilir. Acaba yarı parlamenter kavramı da iki hükümet sistemi modelinin arasını veya ortasını belirtmek için mi kullanılmaktadır? Yarı parlamenter kavramı değişken bir hükümet sistemi modelini ifade etmek için mi tercih edilmiştir? Ya da yarı parlamenter kavramı ile parlamenter sisteme olan yakınlığa mı dikkat çekilmektedir?

$\mathrm{Bu}$ gibi sorulara yanıt verebilmek için yarı parlamenter kavramının doktrinde nasıl kullanıldığına değinmek gerekmektedir. Çalışmamızın konusu Ganghof tarafindan ortaya konan yarı parlamenter sistem olmakla birlikte, yarı parlamenter kavramının Ganghof'tan önce de doktrinde kullanıldığ 1

9 Duverger, s. 165.

10 Lijphart, s. 8.

11 Nur Uluşahin, Saf Hükümet Sistemleri Karşısında İki Başlı Yürütme Yapılanması, Yetkin Yayınları, 2007, s. 34-36. Yarı başkanlık kavramıyla ilgili görüşler için bkz. Aynı eser s. 4249. 
görülmektedir ${ }^{12}$.

Duverger, İsrail'in 1996-2003 yılları arasında uyguladığı sistemin yar1 parlamenter sistem olduğunu ifade etmiştir ${ }^{13}$. Duverger'in böyle bir değerlendirme yapmasında, bahsi geçen dönemde İsrail'de uygulanan hükümet sisteminin kendine özgü niteliğe sahip olması ve yerleşik hükümet sistemi modelleriyle açıklanamaması etkili olmuştur. Gerçekten de İsrail'in kısa süreliğine uyguladığ 1 hükümet sisteminde yürütme organı ikili yapıya sahiptir. Bir tarafta Cumhurbaşkanı, diğer tarafta ise Başbakan ve Hükümet bulunmaktadır. Yasama organı (Knesset) tarafından seçilen Cumhurbaşkanı sembolik bir konumdadır. Başbakan ise iki turlu bir seçim ile doğrudan halk tarafından seçilmektedir. Başbakan ile yasama organının seçimleri birlikte yapılmaktadır. Hükümet, görevine devam edebilmek bakımından yasama organının güvenine tabidir. Diğer bir deyişle, yasama organı güvensizlik oyu ile hükümeti düşürebilmektedir. Başbakana da Cumhurbaşkanının onayı ile erken seçim kararı alarak yasama organının görevine son verebilme yetkisi tanınmıştır. Her iki durumda Başbakan ve yasama organı birbirlerinin görevlerine son verirken, aynı zamanda kendi görevlerine de son vermekte ve yeni seçimler birlikte yapılmaktadır ${ }^{14}$.

Fabbrini, 1993 yılında Seçim Kanununda yapılan değişikliklerin İtalya’y1 yarı parlamenter sistem haline getirdiğini ifade etmiştir. Bu değişiklikler, yukarıda bahsi geçen İsrail sistemine benzemekle birlikte, ondan farklı olarak yerel yönetimleri esas almaktadır. Değişikliğe göre, İtalya'da belediye başkanları ile belediye meclisleri doğrudan halk tarafından ve birlikte yapılan seçimlerle seçilmektedir. Belediye meclisinin, belediye başkanını güvensizlik oyu ile görevden alma yetkisi bulunmaktadır ancak bu durumda belediye başkanı ve belediye meclisinin yeniden seçilmesi gerekmektedir ${ }^{15}$.

Bir başka yazar Linz'in yarı parlamenter kavramını kullanma biçimi, yarı başkanlık kavramını karşılayacak biçimdedir. Linz her iki kavramı birbirleri yerine kullanarak, devlet başkanının halk tarafından seçildiği ve başbakanın

12 Ganghof, s. 277, dn. 1.

13 Maurice Duverger, "Reflections: The Political System of the European Union”, 1997, 31(1), European Journal of Political Research, s. 137.

14 İsrail'in uyguladığı sistem hakkında ayrıntılı bilgi için bkz. Erdal Onar, İsrail'in Kendine Özgü Bir Hükümet Sisteminden Eskisine Geri Dönüşü, 72 Tasarım, 2003, s. 39-43.

15 Sergio Fabbrini, "Features and Implications of Semi-Parliamentarism: The Direct Election of Italian Mayors", 2001, 6(2), South European Society and Politics, s. 47-70. 
parlamentonun güvenoyuna tabi olduğu sistemleri yarı parlamenter veya yarı başkanlık olarak ifade etmektedir ${ }^{16}$.

Nihayet Sartori ise yarı parlamenter kavramını, parlamanter sistemin işleyişiyle bağlantı kurarak kullanmaktadır. Yazara göre, yasama ve yürütme organları arasındaki ayrımda parlamentonun egemen konumda olması halinde parlamenter sistemin iyi işlemesi zorlaşır. Parlamenter sistem, yarı parlamenter bir biçim aldığında, yani başbakan parlamentoya hakim olduğunda daha iyi işleyebilir ${ }^{17}$.

Görüldügü üzere, Ganghof'tan önce yarı parlamenter kavramı dokrinde farklı anlamlara gelecek şekilde kullanılmış, ancak ayrı bir sistem şeklinde unsurları tespit edilmemiştir. Dolayısıyla, yarı parlamenter kavramının bu dönemki kullanılış biçimine dayanarak diğer hükümet sistemi modellerine göre konumunu belirlemek mümkün görünmemektedir. Yukarıda yarı başkanlık kavramından hareketle, yarı parlamenter kavramının kullanılış biçimi hakkında ortaya çıkan sorular da Ganghof'un ortaya attı̆̆1 yarı parlamenter sistem bakımından anlam kazanmaktadır.

\section{GANGHOF'A GÖRE YARI PARLAMENTER KAVRAMI VE YARI PARLAMENTER SISTEMIN TANIMLAYICI UNSURLARI}

Ganghof'un kurumsallaştırdığı hükümet sistemi modeli için yarı parlamenter kavramını kullanması belli bir zaman içinde gerçekleşmiştir. İlk olarak 2012 yılında yayınladığı çalışmasında Ganghof, bazı koşulların varlığ halinde iki meclisli yasama organlarının ayrı bir hükümet sistemi modeli oluşturduğunu belirtmiştir. Sonraları yarı parlamenter olarak nitelendireceği bu hükümet sistemi modelinin özelliklerini açıklayan Ganghof, Avustralya ve Japonya'nın parlamenter sisteme sahip olmadığını ileri sürmüştür ${ }^{18}$.

Ganghof'un ortaya koyduğu hükümet sistemi modelini yarı parlamenter olarak nitelendirmesi ise 2017 yılında yayınladığı çalışmasıyla gerçekleşmiştir. Ganghof bu çalışmada, yarı parlamenter sistemi yeni bir hükümet sistemi

16 Juan J. Linz, "Presidential or Parliamentary Democracy: Does It Make a Difference?" in Juan J. Linz/ Arturo Valenzuela (Eds.), The Failure of Presidential Democracy, The Johns Hopkins University Press, 1994, s. 48.

17 Giovanni Sartori, Karşılaştırmalı Anayasa Mühendisliği; Yapılar, Özendiriciler ve Sonuçlar Üzerine Bir İnceleme, Ergun Özbudun (Çev.), Yetkin Yayınları, 1997, s. 147, 179.

18 Steffen Ganghof, "Bicameralism As a Form of Government (Or: Why Australia and Japan Do Not Have a Parliamentary System)", 2014, 67(3), Parliamentary Affairs, s. 647-663. 
modeli olarak sunmuştur. Aynı zamanda yarı parlamenter sistemin özelliklerini etraflıca açıklayarak Avustralya ve Japonya'nın bu sisteme sahip olduğunu ifade etmiştir ${ }^{19}$. Bu çalışmayı, Ganghof'un birkaç arkadaşıyla yaptı̆̆ 1 ve Avustralya iki meclisliliğini yarı parlamenter olarak inceleyen başka bir çalışma izlemiştir ${ }^{20}$.

Bahsi geçen çalışmalar göz önünde bulundurulduğunda, Ganghof'un yarı parlamenter kavramını, yarı başkanlık kavramından hareketle kullandığ görülmektedir. Ganghof'a göre yarı parlamenter sistem, yarı başkanlık sisteminin aynadaki görüntüsüdür ${ }^{21}$. Yarı başkanlık sisteminde yürütme, eşit derecede meşru iki bölüme ayrılmakta ve bu bölümlerden biri (başbakan) yasama organının güvenine bağlı olmaktadır. Yarı parlamenter sistemde ise yasama organı eşit derecede meşru iki bölüme ayrılmakta ve bu bölümlerden biri başbakana güvensizlik oyu verebilmektedir ${ }^{22}$.

Yasama organının bölümlerinden, iki meclisli yasama organlarında (bicameralism) üst meclis (upper house) ile alt meclis (lower house) anlaşılmaktadır. Alt meclis, doğrudan halk tarafından seçilerek oluşmaktadır. Ganghof, yarı parlamenter sistemi ortaya atarken ise hükümet sistemlerinin sınıflandırılmasında üst meclislerin genellikle ihmal edildiğini, doğrudan halk tarafindan seçilen bir üst meclisin, alt meclis kadar meşru olduğunu ve bu durumu ayrıca incelemeye değer bulduğunu ifade etmektedir ${ }^{23}$.

Şu halde yarı parlamenter sistemin, yasama organının doğrudan halk tarafından seçilen iki bölümden oluşması esas alınarak, yarı başkanlık sisteminin tersi bir mantıkla kurgulandığı anlaşılmaktadır. Yasama organının doğrudan halk tarafindan seçilen iki bölümden oluşması, yarı parlamenter sistemi karakterize eden temel unsurdur ancak tek başına yeterli değildir. Ganghof'a göre, bir hükümet sistemi modelinin yarı parlamenter olarak nitelendirilebilmesi için üç unsura birden sahip olması gerekir. Bu unsurlar şu şekildedir:

19 Ganghof, “A New Political System Model”, s. 261-281.

20 Steffen Ganghof/ Sebastian Eppner/ Alexander Pörschke, "Australian Bicameralism as Semi-Parliamentarism: Patterns of Majority Formation in 29 Democracies", 2018, 53(2), Australian Journal of Political Science, s. 211-233.

21 Aynadaki görüntü ifadesi ile bir görüntünün aynada ters yansımaya sahip olması anlatılmak istenmektedir.

22 Ganghof, “A New Political System Model”, s. 261.

23 Ganghof, “A New Political System Model”, s. 263. 
1. Yürütmenin başının veya devlet başkanının halk tarafindan seçilmemesi,

2. Yasama organının doğrudan halk tarafından seçilen iki bölümden oluşması,

3. Yürütme organının (hükümetin) görevine devam edebilmesinin, yasama organının bir bölümünün güvenine bağlanması, yasama organının diğer bölümünün ise bu konuda yetkisinin bulunmamas ${ }^{24}$.

Bahsi geçen unsurları Ganghof'un görüşleri doğrultusunda ayrı ayrı ele alalım.

\subsection{Yürütmenin Başının veya Devlet Başkanının Halk Tarafından Seçilmemesi}

Ganghof'un ortaya koyduğu yarı parlamenter sistemin tanımlayıc1 unsurları arasında yürütme organının yapısı, yani yürütme organının tekli veya ikili olması ile ilgili bir ifadeye yer verilmemektedir. Ancak ilerleyen kısımda üzerinde durulacağı üzere, yarı parlamenter sistemin üçüncü tanımlayıc1 unsurunda hükümetin görevine devam edebilmesi, yasama organının güvenine bağlanmaktadır. Devlet başkanının yanında güvenoyu mekanizması ile görevine son verilen bir hükümetin bulunduğunun belirtilmesi yarı parlamenter sistemde yürütme organının ikili yapıya sahip olduğunu göstermektedir.

İkili yürütme yapısı içinde devlet başkanının konumunun düzenlenme biçimi, ortaya konan hükümet sisteminin anlaşılması bakımından önemlidir. Zira hükümet sistemi türlerine ilişkin sınıflandırmalarda devlet başkanının seçimi, anayasal yetkileri gibi onun konumunu belirleyen unsurlara yer verilmektedir. Ganghof da yarı parlamenter sistemi tanımlarken ilk olarak, bu sistemde devlet başkanının halk tarafından seçilmemesi gerektiğini ifade etmektedir. Devlet başkanının halk tarafindan seçilmemesinin ne anlama geldiğini açıklayabilmek için halk tarafından seçilmenin anlamını ve kapsamını ortaya koymak gerekmektedir.

Devlet başkanının halk tarafından seçilmesinde (popular election) kullanılan en yaygın yöntem doğrudan (direct) seçimlerdir. Bu yöntemde, devlet başkanı belli süreliğine arada herhangi bir seçiciler kurulu olmaksızın

24 Ganghof, “A New Political System Model”, s. 264. 
doğrudan halk tarafından seçilmektedir. Yapılan seçimler, bir ya da birden fazla turlu olabilmektedir. Devlet başkanının halk tarafından seçilmesinde kullanılan diğer bir yöntem ise bir seçiciler kurulu aracılığıyla seçimlerin gerçekleştirilmesidir. $\mathrm{Bu}$ yöntemde halk öncelikle bir seçiciler kurulu seçmekte ve bu seçiciler kurulu da devlet başkanını seçmektedir. Bu yöntemin uygulandığ en bilinen örnek olan Amerika'da halkın seçtiği seçiciler kurulu, devlet başkanını seçerken halkın tercihleriyle bağlıdır ve kendi tercihleri doğrultusunda hareket edememektedir ${ }^{25}$. Diğer yandan, halkın seçmiş olduğu seçiciler kuruluna, devlet başkanını seçerken kendi tercihleri doğrultusunda hareket edebilme imkânı da tanınabilmektedir. 1919 tarihli önceki Anayasasında, 1991 yılında yapılan değişikliğe kadar Finlandiya'da devlet başkanı bu şekilde seçilmiştir ${ }^{26}$. Bu durumda da devlet başkanının halk tarafından seçildiğini kabul etmek gerekmektedir ${ }^{27}$. Zira devlet başkanını seçen kurul, sırf bu amaçla ve halk tarafından seçilerek oluşturulmaktadır ${ }^{28}$.

Devlet başkanının halk tarafından seçilmesi, doğrudan yapılan seçimler ile halkın seçtiği seçiciler kurulu aracılığıyla yapılan seçimleri ifade ettiğine göre, Ganghof'un ortaya koyduğu yarı parlamenter sistemde bahsi geçen iki yöntemle devlet başkanının seçilmemesi gerektiği söylenebilir. Dolayısıyla, devlet başkanının diğer seçilme yöntemleri yarı parlamenter sistemde söz konusu olabilir. Yani monarşinin uygulandığı yarı parlamenter bir sistemde devlet başkanının seçilmesi veraset yoluyla gerçekleştirilebilir. Esasen bu durumda, gerçek bir seçim faaliyetinden ziyade devlet başkanının veraset kurallarına göre belirlenmesi söz konusudur. Bunun dışında yarı parlamenter

25 Robert Elgie, "The President of Ireland in Comparative Perspective", 2012, 27(4), Irish Political Studies, s. 503; Sartori, s. 115.

26 Elgie, "The President of Ireland in Comparative Perspective", s. 503; Arend Lijphart, Patterns of Democracy; Government Forms and Performance in Thirty-Six Countries, Second Edition, Yale University Press, 2012, s. 111.

Ayrıca bkz. 1919 Finlandiya Anayasası m.23.

27 Bununla birlikte, halk tarafından seçilen bir seçiciler kurulu aracılığıyla devlet başkanının seçilmesi yönteminin doktrinde farklı şekillerde nitelendirildiği görülmektedir. Elgie'ye göre, bu durumda devlet başkanı doğrudan benzeri (direct-like) bir seçimle seçilmektedir. Bkz. Elgie, "The President of Ireland in Comparative Perspective", s. 503. Shugart ve Carey ise devlet başkanının bu yöntemde dolaylı olarak halk tarafından seçildiğini ifade etmektedir. Bkz. Shugart/ Carey, s. 20, dn. 4. Sartori, konuyu daha ayrıntılı ele alarak ikili bir ayrıma gitmektedir. Yazara göre, seçiciler kurulu devlet başkanını seçerken Amerika örneğinde olduğu gibi kendi tercihleri doğrultusunda hareket edemiyorsa doğrudan benzeri bir seçim; Finlandiya örneğinde olduğu gibi kendi tercihleri doğrultusunda hareket edebiliyorsa dolaylı olarak halk tarafından seçim söz konusu olmaktadır. Bkz. Sartori, s. 115, 175.

28 Shugart/ Carey, s. 20, dn. 4. 
sistemde devlet başkanı yasama organı tarafından seçilebilir. Ayrıca yasama organı üyeleri ile yerel makamların temsilcilerinden oluşan bir kurul da yarı parlamenter sistemde devlet başkanını seçebiliir ${ }^{29}$. Bu son durumda devlet başkanı bir kurul tarafından seçilse de bu kurul, devlet başkanını seçmek amacıyla halk tarafından seçilerek oluşturulan bir kurul değildir.

Devlet başkanının seçilme yöntemi açısından diğer hükümet sistemi modelleri ile karşılaştırıldığında yarı parlamenter sistemin, başkanlık ve yarı başkanlık sistemlerine benzemediği açıktır. Zira başkanlık ve yarı başkanlık sistemlerinde devlet başkanı halk tarafından seçilirken, yarı parlamenter sistemde devlet başkanının halk tarafından seçilmesi mümkün değildir.

Parlamenter sistemde ise devlet başkanının halk tarafından seçilip seçilmeyeceği doktrinde tartışmalıdır. Bu tartışmalar, yasama organına karşı sorumlu bir hükümetin yanında devlet başkanının bulunduğu ikili yürütme yapılarında, devlet başkanının halk tarafından seçilmesinin, sistemi parlamenter olmaktan çıkarıp yarı başkanlık haline getirip getirmeyeceğine odaklanmaktadır. Bir görüşe göre, ikili yürütme içinde devlet başkanının halk tarafından seçilmesi halinde yarı başkanlık sisteminden söz edilmektedir. Devlet başkanının yetkilerinin boyutu, diğer bir deyişle önemli yetkilere sahip olup olmaması sistemin nitelendirilmesi açısından önem arz etmemektedir ${ }^{30}$. Bizim de katıldığımız diğer görüşe göre ise ikili yürütme yapılarında halk tarafindan seçilen devlet başkanının aynı zamanda önemli yetkilere sahip olması halinde yarı başkanlık sisteminden bahsedilmektedir ${ }^{31}$. Şu halde, oldukça sınırlı yetkilere sahip bir devlet başkanının halk tarafından seçilmesi, sistemi parlamenter olmaktan çıkarmaya yetmeyecektir ${ }^{32}$.

29 Elliot Bulmer, Non-Executive Presidents in Parliamentary Democracies, Second Edition, International IDEA Constitution-Building Primer 6, 2017, s. 14; Elgie, "The President of Ireland in Comparative Perspective", s. 503.

30 Robert Elgie, "The Politics of Semi-Presidentialism" in Robert Elgie (Ed.), SemiPresidentialism in Europe, Oxford University Press, 1999, s. 13.

31 Bu görüşün temelleri yarı başkanlık sistemini kurumsallaştıran Duverger'e dayanmaktadır. Duverger'e göre bir siyasal sistemin yarı başkanlık olarak nitelendirilebilmesi için şu üç unsura sahip olması gerekmektedir: Devlet başkanının halk tarafından seçilmesi, devlet başkanının oldukça önemli yetkilere sahip olması ve devlet başkanının yanında yürütme yetkilerine sahip olan, parlamentonun güvenine tabi bir hükümetin bulunmasi. Bkz. Duverger, “A New Political System Model”, s. 166.

32 Shugart, ikili yürütme yapısı içinde önemli yetkilere sahip olmayan fakat halk tarafından seçilen devlet başkanının bulunduğu siyasal sistemleri başkanlı parlamenter sistem (parliamentary with president system) olarak tanımlamaktadır. Yazara göre, yasamayürütme ilişkilerinin işleyişi bakımından başkanlı parlamenter sistem ile parlamenter sistem 
Halk tarafindan seçilme ile ilgili tartışmalar bir yana bırakıldığında, parlamenter sistemde devlet başkanının yasama organı tarafından veya yasama organı üyeleri ile yerel makamların temsilcilerinden oluşan bir kurul tarafından seçilmesi asıldır. Ayrıca parlamenter sisteme sahip monarşilerde devlet başkanı veraset kurallarına göre belirlenmektedir. Şu halde, yarı parlamenter sistemin devlet başkanının seçilme yöntemi açısından parlamenter sisteme benzediği görülmektedir.

\subsection{Yasama Organının Doğrudan Halk Tarafından Seçilen İki Bölümden Oluşması}

Ganghof'un ortaya koyduğu yarı parlamenter sistemin ikinci unsuru, yasama organının iki bölümden oluşması ve bunlardan her birinin doğrudan halk tarafından seçilmesidir. Yasama organının iki bölümden oluşması, üst meclis ile alt meclisin bulunduğu iki meclisli yapıları ilk olarak akla getirmektedir. Ancak Ganghof'un "iki meclis" yerine "iki bölüm” ifadesini kullanmış olması rastlantısal değildir. Ganghof, yarı parlamenter sistemin iki meclisli yapılarda bulunabileceğini belirtmekle birlikte, bu sistemin tek meclisli yapılarda da var olabileceğini kabul etmektedir. Buna göre, halk tarafından seçilmiş tek meclisli yasama organında üyeler, belli oranlarla görevleri yönünden birbirlerinden farklı iki bölüme ayrılıyorsa yine yarı parlamenter sistemden bahsedilebilir ${ }^{33}$. Yani "iki bölüm" ifadesi daha geniş ve "iki meclis" ifadesini de içine alacak bir biçimde kullanılmıştır. Bu konuya bir alt başlıkta tekrar değinilecektir.

Ganghof, yasama organının iki bölümü için "doğrudan seçim" ifadesini kullanmaktadır. Dikkat edilirse, yarı parlamenter sistemde devlet başkanının halk tarafından seçilmemesi gerektiği açıklanırken, halk tarafindan yapılan seçimlerin doğrudan seçimler yanında, halkın seçmiş olduğu bir kurul tarafından yapılan seçimleri de ifade ettiği belirtilmişti. Yasama organının iki bölümü için doğrudan seçim ifadesinin kullanılmasıyla ise halkın seçmiş olduğu bir kurul aracılığıyla seçimlerin gerçekleştirilemeyeceği ayrıca vurgulanmış olmaktadır.

arasında fark bulunmamaktadır ve başkanlı parlamenter sistem de özü itibariyle parlamenter sistemdir. Bkz. Matthew Soberg Shugart, "Of Presidents and Parliaments", 1993, 2(1), East European Constitutional Review, s. 31. Başkanlı parlamenter sistem hakkında ayrıntılı bilgi için ayrıca bkz. Şule Özsoy Boyunsuz, Başkanlı Parlamenter Sistem; Cumhurbaşkanının Halk Tarafından Seçildiği Parlamenter Hükümet Modeli ve Türkiye İçin Tavsiye Edilebilirliği, 2. Bask1, On İki Levha Yayınları, 2014, s. 91 vd.

33 Ganghof, “A New Political System Model”, s. 261, 263. 
Yasama organının doğrudan halk tarafından seçilen iki bölümden oluşmasının, yarı parlamenter sistemin zorunlu unsurlarından biri olarak kabul edilmesi, hükümet sistemlerinin sinıflandırılmasına da farklı bir boyut katmaktadır ${ }^{34}$. Daha önce de belirtildiği gibi, hükümet sistemleri sınıflandırılırken yasama ile yürütme organları arasındaki ilişkinin kuruluşunda, yürütme organının nasıl seçildiğinin ve göreve nasıl devam devam ettiğinin dikkate alınması yaygın bir yaklaşımdı ${ }^{35}$. Bu yaklaşımın, yarı parlamenter sistemde de yansımaları görülmektedir. Zira yarı parlamenter sistemde devlet başkanının halk tarafından seçilemeyeceği belirtilmekte ve hükümetin göreve devam etmesi yasama organının bir bölümünün güvenine bağlanmaktadır. Ancak yarı parlamenter sistemin tanımlayıcı unsurlarında bunlara ek olarak, yasama organının kaynağı yani nasıl seçildiği ile ilgili bir ifadeye yer verilmesi, Ganghof'un yasama organını öne çıartan bir model ortaya koyduğunu göstermektedir ${ }^{36}$.

$\mathrm{Bu}$ noktada, yarı parlamenter sistem tanımında yasama organının görevine nasıl devam ettiği ile ilgili bir ifadeye neden yer verilmediği sorusu akla gelmektedir. Zira yarı parlamenter sistem, yarı başkanlık sisteminin tersi bir mantıkla kurgulanmışsa, yarı parlamenter sistemin tanımlayıcı unsurlarında yasama organının kaynağı ile ilgili bir ifadenin yanında, yasama organının görevine nasıl devam ettiği ile ilgili bir ifadeye de yer verilmesi gerekirdi. Yani yarı parlamenter sistemin tanımlayıcı unsurlarında, doğrudan halk tarafından seçilen yasama organının bölümlerinden birinin ya da her ikisinin feshedilip feshedilemeyeceği belirtilebilirdi ${ }^{37}$. Ganghof'un yar1 parlamenter sistem örneği olarak gösterdiği Japonya'da, Anayasaya göre Temsilciler Meclisi ve Senatodan oluşan yasama organında (Diet) yalnızca Temsilciler Meclisi feshedilebilmektedir ${ }^{38}$. Bir diğer yarı parlamenter sistem örneği olarak işaret edilen Avustralya'da ise Temsilciler Meclisi ve Senatonun eş zamanlı olarak feshedilmesi mümkündür ${ }^{39}$. Dolayısıyla Elgie'nin de

34 Robert Elgie, "On New Forms of Government”, 2018, 53(2), Australian Journal of Political Science, s. 244.

35 Shugart/ Carey, s. 19 vd.; Elgie, "The Classification of Democratic Regime Types", s. 221; Samuels/ Shugart, s. 26-27; Lijphart, "Introduction", s. 5-6.

36 Elgie, "On New Forms of Government", s. 244.

37 Elgie, "On New Forms of Government", s. 244.

381946 Japonya Anayasasına göre İmparator, Bakanlar Kurulunun önerisi ve onayıyla Temsilciler Meclisini fesheder (m.7).

391901 Avustralya Anayasası, kanun yapım sürecinde Temsilciler Meclisi ile Senato arasında uyuşmazlık çıkması halinde, belli anayasal koşullar altında Genel Vali’ye her iki Meclisi 
belirttiği gibi, yasama organının feshi ile ilgili bir ifadenin yarı parlamenter sistemin tanımına eklenmesi, bu sistemin kendi içindeki farklılıklarının ortaya çıkmasını sağlayacaktır ${ }^{40}$.

\subsection{Yürütme Organının Görevine Devam Edebilmesinin, Yasama Organının Bir Bölümünün Güvenine Bağlanması}

Yasama organının iki bölümden oluşmasının yarı parlamenter sistemin tanımlayıcı unsurlarından biri olduğu yukarıda açıklanmıştı. Ganghof tarafindan ortaya konan yarı parlamenter sistemin diğer bir unsuru, yürütme organının görevine devam edebilmesinin, yasama organının bölümlerinden birinin güvenine bağlanmasıdır. Diğer bir deyişle, yarı parlamenter sistemde yürütme organ1, yasama organının bir bölümüne karşı sorumlu olmakta ve bu sorumluluk gereği yürütme organının görevine, yasama organının bir bölümünün güvensizlik oyu ile son verilebilmektedir. Yarı parlamenter sistemde yürütme organı devlet başkanı ve hükümetten oluştuğundan, yasama organının bir bölümüne karşı sorumlu tutulan yürütme organından hükümeti anlamak gerekmektedir.

Hükümetin yasama organına karş1 sorumluluğunun, parlamenter sistemin tarihsel gelişimi içinde ortaya çıtı $\breve{g}_{1}{ }^{11}$ ve bu sistemin temel bir özelliği olduğu bilinmektedir. Bu nedenle de parlamenter sistem ile ilgili tanımlamalar, hükümetin yasama organına karşı sorumluluğu üzerinden yapılmaktadır ${ }^{42}$. Hatta parlamenter sistem için "sorumlu hükümet sistemi"

feshetme yetkisi tanımaktadır (m.57).

40 Elgie, "On New Forms of Government", s. 244.

${ }^{41}$ İngiltere'de yürütme yetkisinin Kral'dan ayrılarak hükümete geçmesi ile hükümet, yetkili ve sorumlu bir makam haline gelmiş ve görevine devam edebilmek bakımından yasama organının güvenine ve desteğine ihtiyaç duymuştur. Parlamenter sistemin tarihsel gelişimi ve hükümetin yasama organına karşı sorumluluğu ile ilgili bkz.

Wolfgang C. Müller/ Torbjörn Bergman / Kaare Strøm, "Parliamentary Democracy: Promise and Problems", in Wolfgang C. Müller/ Torbjörn Bergman/ Kaare Strøm (Eds.), Delegation and Accountability in Parliamentary Democracies, Oxford University Press, 2006, s. 6-7.

42 Leon D. Epstein, "Parliamentary Government", in David L. Sills (Ed.), International Encyclopedia of the Social Sciences, 11, Macmillian and Free Press, 1968, s. 419; Lijphart, Patterns of Democracy, s. 106; John M. Carey, "Presidential versus Parliamentary Government", in Claude Menard/ Mary M. Shirley (Eds.), Handbook of New Institutional Economics, Springer, 2005, s. 91; Sartori, s. 137; Müller/ Bergman/ Strøm, s. 12-13; José Antonio Cheibub, Presidentialism, Parliamentarism, and Democracy, Cambridge University Press, 2007, s. 35-36. 
ifadesinin kullanıldığg görülmektedir ${ }^{43}$. Parlamenter sistemin bu özelliği, yar1 başkanlık sisteminde de yer almaktadır ${ }^{44}$. Doktrinde yarı başkanlık sisteminin tanımıyla ilgili tartışmalar olsa da bu tartışmalar, ikili yürütme içinde genellikle devlet başkanıyla ilgilidir ${ }^{45}$. Yürütmenin diğer tarafı olan hükümetin, yasama organına karşı sorumluluğu ile ilgili ise bir tartışma bulunmamaktadı4 ${ }^{46}$.

$\mathrm{Bu}$ açıklamalar doğrultusunda yarı parlamenter sistemde -yarı başkanlık sisteminde olduğu gibi- parlamenter sistemin temel bir özelliğinin benimsendiği ifade edilebilir. Ancak yarı parlamenter sistemde hükümetin, yasama organının bir bölümünün güvenine bağlandığını ayrıca vurgulamak gerekmektedir. Yani yarı parlamenter sistemin ayırıcı noktası, hükümetin yasama organının bir bölümüne karşı sorumluluğunun bulunması, yasama organının diğer bölümüne karşı ise böyle bir sorumluluğunun olmamasıdır. $\mathrm{Bu}$ durum, hükümet sistemlerinin sinıflandırılmasındaki ve ülkelerin

43 William MacDonald, A New Constitution For A New America, B. W. Huebsch, 1921, s. 25.

$44 \mathrm{Bu}$ noktada hükümetin yasama organına karşı sorumluluğunun kuvvetlerin sert ayrılığına dayanan başkanlık sisteminin bir özelliği olmadığını belirtmek gerekir. Ancak başkanlık sistemine, parlamenter sisteme ait unsurlar ekleyen bazı Latin Amerika ülkelerinde bakan ya da bakanların sorumluluğuna yasama organları tarafindan gidilebilmektedir. Bolivya (m.158), Kolombiya (m.135), Guatemala (m.166, 167), Peru (m.132), Venezuela (m.246) ve Uruguay (m.148) Anayasalarında bu yönde düzenlemeler yer almaktadır.

45 Daha önce de kısmen değinildiği gibi bu tartışmalar, devlet başkanının seçimi ve önemli yetkilere sahip olup olmaması üzerine şekillenmektedir. Bir görüşe göre, yarı başkanlık sisteminin söz konusu olabilmesi için yasama organına karşı sorumlu olan hükümetin yanında halk tarafından seçilen ve önemli yetkilere sahip olan bir devlet başkanı bulunmalıdır. Bkz. Duverger, “A New Political System Model”, s. 166. Diğer görüşe göre, yasama organına karşı sorumlu hükümetle birlikte halk tarafından seçilen devlet başkanının bulunması o siyasal sistemin yarı başkanlık olarak nitelendirilebilmesi için yeterlidir. Devlet başkanının önemli yetkilere sahip olup olmaması yarı başkanlık sisteminin bir unsuru değildir. Bkz. Elgie, "The Politics of Semi-Presidentialism" s. 13. Burada yer verilmesi gereken üçüncü görüş ise yarı başkanlık sistemini tanımlarken devlet başkanının seçilme yöntemini dikkate almamaktadır. Buna göre yarı başkanlık sisteminden bahsedilebilmesi için yürütme yetkisinin devlet başkanı ile başbakan arasında bölünmesi ve devlet başkanının önemli yetkilere sahip olması gerekmektedir. Bkz.

Patrick O'Neil, "Presidential Power in Post-Communist Europe: The Hungarian Case in Comparative Perspective", 1993, 9(3), Journal of Communist Studies, s. 197, dn. 4.

46 Duverger, "A New Political System Model", s. 166; Elgie, "The Politics of SemiPresidentialism" s. 13; Linz, s. 48. Shugart ve Carey yarı başkanlık sistemi yerine başbakancı başkanlık sistemi (premier- presidential system) ve başkancı parlamenter sistem (presidentparliamentary system) şeklinde iki alt sınıflandırma yapmaktadır. Bu sistemlerin her ikisinde de hükümetin yasama organına karşı sorumluluğu bulunmaktadır. Bkz. Shugart / Carey, s. 23-25. Ayrica bkz. Matthew Soberg Shugart, "Semi-Presidential Systems: Dual Executive and Mixed Authority Patterns", 2005, 3(3), French Politics, s. 333; Shugart, "Of Presidents and Parliaments", s. 30. 
benimsediği hükümet sistemlerinin belirlenmesindeki genel yaklaşımdan farklılık arz etmektedir. Parlamenter sistem ve yarı başkanlık sistemi ile ilgili yapılan tanımlamalarda genel yaklaşım, hükümetin yasama organına karşı sorumluluğunun bulunduğunun belirtilmesinden ibarettir. $\mathrm{Bu}$ sorumluluğun yasama organının bir bölümü ya da tamamına karşı olmasının sınıflandırma açısından önemi bulunmamaktadır ${ }^{47}$. Örneğin, Fransa'da hükümetin sorumluluğu yasama organını oluşturan iki meclisten birine karşı iken ${ }^{48}$; Romanya'da hükümetin sorumluluğu yasama organını oluşturan iki meclise karşıdır ${ }^{49}$. Bu durumda Fransa ve Romanya, hükümetin yasama organına karşı sorumlu olması koşulunu taşımakta ve diğer koşullara da sahip oldukları düşünüldügünde, her iki ülke yarı başkanlık olarak değerlendirilmektedir ${ }^{50}$. Aynı şekilde Almanya'da yasama organını oluşturan meclislerden biri tarafindan hükümetin sorumluluğuna gidilebilirken ${ }^{51}$; İtalya'da hükümetin sorumluluğu her iki meclise karşıdır ${ }^{52}$. Ancak iki ülkenin de parlamenter sisteme sahip olduğu konusunda tereddüt bulunmamaktadır. Şu halde, yarı parlamenter sistemde hükümetin sorumluluğunun yasama organının yalnızca bir bölümü için öngörülmesi, hükümet sistemlerinin sınıflandırılması açısından yeni bir yaklaşım şeklinde değerlendirilebilir.

\section{GANGHOF'UN İDEAL BİR YARI PARLAMENTER SISTEM TASARIMI}

Ganghof, bir hükümet sistemi modelinin yarı parlamenter olarak nitelendirilebilmesi için yukarıda açıklanan üç unsura sahip olmasını yeterli kabul etmektedir. $\mathrm{Bu}$ unsurlar, yarı parlamenter olarak sunulan sistemin çerçevesini belirleyen düzenlemeler içermektedir. Diğer yandan Ganghof, bu unsurlardan hareket ederek ideal bir yarı parlamenter sistem tasarlamakta ve böylelikle yarı parlamenter sistemin, özellikle iki meclisli yasama organları bakımından somutlaştırılmasını ve daha iyi anlaşılmasını sağlamaktadır.

Ganghof'a göre, halk tarafindan seçilen iki bölüme sahip yasama organının bulunması ve hükümetin sorumluluğunun yasama organının bölümlerinden birine karşı olması, ideal bir yarı parlamenter sistem bakımından

47 Elgie, "On New Forms of Government", s. 242.

481958 Fransa Anayasas1 m.49, 50.

491991 Romanya Anayasası m.113, 114.

50 Elgie, “On New Forms of Government", s. 242.

$51 \quad 1949$ Almanya Anayasası m.67, 68.

521947 İtalya Anayasası m.94. 
varılması gereken bazı sonuçlar ortaya çıkarmaktadır ${ }^{53}$. Buna göre ideal bir yarı parlamenter sistemde;

1. Yasama organının her iki bölümü eşit demokratik meşruluğa sahip olmalıdır.

2. Yürütme organının görevine devam edebilmesi, yasama organının bir bölümünden bağımsız olmalıdır.

3. Yasama organının ayrılan bu bölümü, kanun yapım sürecinde mutlak veto yetkisine sahip olmalıdır ${ }^{54}$.

Bu sonuçların, yarı parlamenter sistemin tanımlayıcı unsurlarıyla birlikte değerlendirilerek ayrı ayrı ele alınması gerekmektedir.

\subsection{Yasama Organının Her İki Bölümünün Eşit Demokratik Meşruluğa Sahip Olması}

Yasama organının doğrudan halk tarafından seçilen iki bölümden oluşması, yarı parlamenter sistemi tanımlayan unsurlardan biri olarak açıklanmıştı. İdeal bir yarı parlamenter sistemde ise yasama organının her iki bölümünün eşit demokratik meşruluğa sahip olması gerektiğine dikkat çekilmektedir. Esasen, yarı parlamenter sistemde yasama organının iki bölümünün doğrudan halk tarafından seçilmesi ile yasama organının bölümleri demokratik açıdan eşit meşruluğa sahip olmaktadır ${ }^{55}$.

Bu noktada, doğrudan halk tarafından seçilmeyen ancak seçilme yöntemi açısından demokratik meşruluğa sahip olan üyelerin bulunduğu yasama organına sahip bir ülkenin yarı parlamenter sistem kapsamında değerlendirilip değerlendirilmeyeceği sorgulanmalıdır. Zira iki meclisli yasama organına sahip ülkelerde üst meclis olan Senatoların üyelerinin tamamının doğrudan halk tarafindan seçilmemesine sıklıkla rastlanmaktadır. Böyle bir durumda, diğer koşullar da mevcutsa yarı parlamenter sistemden bahsedilebilecek midir? $\mathrm{Bu}$ soruya yarı parlamenter sistemin tanımlayıcı unsurlarından hareketle olumsuz cevap vermek gerekmektedir. Tanımlayıcı unsurlar açık bir biçimde ortaya konulduğundan, bu konuda öznel bir değerlendirmede bulunmak mümkün değildir ${ }^{56}$.

\footnotetext{
53 Ganghof, “A New Political System Model”, s. 265.

54 Ganghof, “A New Political System Model”, s. 265-266.

55 Ganghof, “A New Political System Model”, s. 265.

56 Ganghof/ Eppner/ Pörschke, s. 215.
}

854 Ankara Hacı Bayram Veli Üniversitesi Hukuk Fakültesi Dergisi C. XXV, Y. 2021, Sa. 2 
Aynı soruya Ganghof'un belirlemiş olduğu ideal yarı parlamenter sistem açısından bakıldığında ise yanıt değişebilmektedir. Zira Ganghof, yarı parlamenter sistemin ideal biçiminde, yasama organının iki bölümünün eşit meşruluğa sahip olması konusundaki bazı sapmalara karşı çıkmamaktadır. $\mathrm{Bu}$ anlamda Ganghof, Almanya ve Hollanda' da olduğu gibi doğrudan seçilmeyen ancak demokratik meşruluğu yüksek olan üst meclisler bakımından yarı parlamenter sistemin tartışılmasına olumlu yaklaşmaktadır ${ }^{57}$. Benzer şekilde Ganghof, üst meclislerin üyelerinin bir kısmının doğrudan halk tarafından seçilmesi halinde, bu yolla seçilen üyelerin oranına göre bir değerlendirmede bulunulabileceğini belirtmektedir ${ }^{58}$. Yani üst mecliste doğrudan seçilen üye, belli bir oranın üstünde ise yarı parlamenter sistem için gerekli koşulun sağlandığından söz edilebilecektir. Bu durumda oranın ne olacağı ve nasıl belirleneceği öznel değerlendirmeleri beraberinde getirmektedir ${ }^{59}$. Örneğin, İtalya'da üst meclisin yüzde 98,5 'i doğrudan seçilmekte, diğer üyeler atanmaktadır. Bu orana bakıldığında üst meclisin doğrudan seçildiği ve alt meclisle eşit meşruluğa sahip olduğu düşünülebilir. Ancak bu durum tamamen öznel değerlendirmeye bağlı olduğundan, daha düşük oranda doğrudan seçilen üyesi bulunan üst meclise sahip ülkelerin yarı parlamenter olarak değerlendirilmesine de engel bulunmamaktadır ${ }^{60}$. Dolayısıyla Ganghof'un, yarı parlamenter sistemin ideal biçimi bakımından, doğrudan seçilmeyen veya bir kısmı doğrudan seçilen üyelere sahip üst meclislerin de yarı parlamenter olarak değerlendirilebileceğine kap1 aralaması, başka yazarlar tarafından farklı ülke sınıflandırmaları yapılması riskini taşımaktadır ${ }^{61}$. Bu durumda yarı parlamenter olarak nitelenen farklı ülke grupları ortaya çıkacak ve yarı parlamenter sistemin belirli sınırlar kapsamında açıklanması zorlaşacaktır.

\subsection{Yürütme Organının Görevine Devam Edebilmesinin, Yasama Organının Bir Bölümünden Bağımsız Olması}

Yar1 parlamenter sistemde, yürütme organının görevine devam edebilmesinin, yasama organının bir bölümünün güvenine bağlandığı yani yürütme organının sorumluluğunun, yasama organının bir bölümüne karş1 olduğu belirtilmişti. İdeal bir yarı parlamenter sistem için ise aynı husus

\footnotetext{
57 Ganghof, “A New Political System Model”, s. 265-266.

58 Ganghof/ Eppner/ Pörschke, s. 227, dn. 3.

59 Elgie, “On New Forms of Government", s. 245.

60 Elgie, "On New Forms of Government", s. 245.

${ }^{61}$ Elgie, "On New Forms of Government”, s. 245-246.
} 
tersinden ifade edilmiş ve yasama organının, yürütme organının görevine devam etmesiyle ilgili güvensizlik oyu verme yetkisi olmayan ayrı bir bölümünün bulunduğu vurgulanmıştır.

Öte yandan, iki meclisli yasama organları düşünüldüğünde, hangi meclisin hükümete güvensizlik oyu verme yetkisine sahip olduğu, hangi meclisin ise böyle bir yetkisi bulunmadığı ideal bir yarı parlamenter sistem bakımından somutlaştırılmaktadır. Bu noktada Ganghof, ideal bir yarı parlamenter sistemde üst meclisin hükümete güvensizlik oyu verme yetkisinin bulunmadığını belirtmek suretiyle, hükümetin sorumluluğunun alt meclise karşı olduğunu ifade etmektedir ${ }^{62}$. Esasen iki meclisli yasama organına sahip ülkelerde de genellikle hükümet, alt meclislere karş1 sorumlu olmaktadır. Zira alt meclisler, doğrudan halk tarafından seçildiğinden öncelikli olarak temsili bir organ şeklinde görülmekte ve hükümetin sorumluluğunu işletecek mekanizmalarla donatılmaktadır ${ }^{63}$. Ancak yarı parlamenter sistem açısından dikkat çekici olan, üst meclisin doğrudan halk tarafindan seçilmesine ve temsili bir niteliğe sahip olmasına rağmen, hükümetin sorumluluğu ile ilgili bir yetkisinin bulunmamasidır.

$\mathrm{Bu}$ durum, hükümetin üst meclise karşı sorumluluğunu doğuran farkl1 mekanizmaların da ideal bir yarı parlamenter sistemde yer almamasını gerektirmektedir. Örneğin üst meclis, hükümet tarafından hazırlanan bütçe kanunu üzerinde mutlak bir veto yetkisine sahipse, bu yetkisini kullanarak hükümetin sorumluluğuna yol açabilir. Dolayısıyla, fiili bir güvensizlik oyu şeklinde kullanılabileceğinden, ideal bir yarı parlamenter sistemde üst meclis bütçe kanunu üzerinde mutlak bir veto yetkisine sahip olmamalıdır ${ }^{64}$.

Yarı parlamenter sistemde, yürütme organının görevine devam edebilmesinde yasama organının bir bölümünün herhangi bir yetkisinin olmamasını, kuvvetler ayrılığı açısından da değerlendirmek gerekmektedir. Zira yürütme organının görevine, yasama organının desteğiyle veya yasama organından bağımsız olarak devam edebilmesi, yasama ve yürütme kuvvetleri arasındaki ayrılığın ne şekilde kurulduğunu büyük ölçüde belirlemektedir. Başkanlık sisteminde yürütme organının görevine yasama organı tarafından son verilememesi esastır ve yürütme organı sabit bir süre için görev

62 Ganghof, “A New Political System Model”, s. 266.

${ }_{63}$ Elliot Bulmer, Bicameralism, Second Edition, International IDEA Constitution-Building Primer 2, 2017, s. 24.

64 Ganghof, “A New Political System Model”, s. 266. 
yapmaktadır. Bu yönüyle başkanlık sisteminde kuvvetlerin sert ayrılı̆̆ından bahsedilmektedir. Parlamenter sistemde ise yürütme organı içinde yetkili tarafı oluşturan hükümet, yasama organının desteğiyle görevine devam edebilmektedir. Yasama organı güvensizlik oyuyla hükümetin görevine son verebildiğinden, yasama ve yürütme kuvvetleri arasında yumuşak bir ayrılık söz konusu olmaktadır.

Ganghof, yarı parlamenter sistemde güvensizlik oyu verme yetkisi olmayan yasama organı bölümü ile yürütme organı arasında başkanlık sisteminde olduğu gibi bir kuvvetler ayrılığı kurulduğunu ifade etmektedir ${ }^{65}$. Yani iki meclisli yasama organları düşünüldüğünde, üst meclis ile yürütme organı arasındaki ayrılığın sınırları kesin bir biçimde belirlenmiştir. Bununla birlikte, yasama organının diğer bölümü olan alt meclis tarafindan hükümete güvensizlik oyu verilebilmesi ise yarı parlamenter sistemde yasama ve yürütme kuvvetleri arasındaki ilişkiyi göstermektedir. Şu halde, yasama organı bir bütün halinde değerlendirildiğinde, yasama ve yürütme kuvvetleri arasındaki ayrılık bakımından yarı parlamenter sistemin hangi hükümet sistemi modeline daha yakın olduğu söylenebilir? Kanaatimizce, yasama organının bir bölümünün güveni söz konusu olsa da hükümetin yasama organının desteğiyle görevde kalabilmesi, yarı parlamenter sistemi bu yönüyle parlamenter sisteme yaklaştırmaktadır. Ayrıca iki meclisli yasama organına sahip olup, bu meclislerden yalnızca birine hükümet hakkında güvensizlik oyu verme yetkisinin tanınması parlamenter sistemde de söz konusu olabilir. Örneğin, daha önce de belirtildiği gibi, parlamenter sisteme sahip Almanya'da, Anayasaya göre meclislerden yalnızca birine bu yönde bir yetki tanınmıştır.

\subsection{Yasama Organının Ayrılan Bölümünün, Kanun Yapım Sürecinde Mutlak Veto Yetkisine Sahip Olması}

Yarı parlamenter sistemde görüldüğ̈̈ üzere, yasama organının bölümlerinden birinin yürütme organının görevine devam etmesinde herhangi bir yetkisi bulunmamaktadır. Diğer bir deyişle, yürütme organıyla ilişkiler konusunda yasama organının bir bölümü ayrı ve bağımsız tutulmaktadır. İki meclisli yasama organı söz konusuysa, ideal bir yarı parlamenter sistemde ayrı tutulan yasama organı bölümünün üst meclis olduğu görülmektedir.

Ganghof, ideal bir yarı parlamenter sistem bakımından ek bir koşulun daha varlığını aramaktadır. Yazara göre, yasama organının ayrılan bölümü,

65 Ganghof, “A New Political System Model”, s. 262. 
yani üst meclis, kanun yapım sürecinde mutlak veto yetkisine sahip olmalıdır ${ }^{66}$. $\mathrm{Bu}$ koşulun, yarı parlamenter sistemin tanımlayıcı unsurları arasında sayılmadığının veya yarı parlamenter sistemin zorunlu bir koşulu olmadığının altını çizmek gerekmektedir. Dolayısıyla üst meclisin kanun yapım sürecinde mutlak veto yetkisine sahip olmaması halinde de diğer koşullar bulunuyorsa yarı parlamenter sistemden bahsedilebilir. Üst meclisin bu yetkiye sahip olmas1 ise yarı parlamenter sistemin ideal bir şekle bürünmesini sağlamaktadır.

Bu noktada, üst meclise tanınan mutlak veto yetkisinin ne anlama geldiği ve sonuçları üzerinde durmak gerekmektedir. Mutlak veto yetkisinin iki meclisli yasama organlarında üst meclislere, yasama faaliyetlerinde kontrol ve dengenin sağlanabilmesi amacıyla tanındığ görülmektedir $^{67}$. Bu yetki, ilk bakışta bir kanun teklifinin üst meclis tarafindan kabul edilmemesi halinde, kanun haline gelememesini ifade etmektedir. Diğer bir deyişle, alt meclis tarafindan kabul edilen bir kanun teklifi, üst meclisin de kabulüyle kanun haline gelebilmektedir ${ }^{68}$. Bu şekliyle düşünüldüğünde, üst meclisin vetosuna rağmen bir kanun teklifinin kanunlaşması mümkün görünmemektedir.

Öte yandan üst meclis tarafindan kabul edilmeyen bir kanun teklifinin kanunlaşmaması, iki meclis arasında çatışmaya ve yasama faaliyetinde kilitlenmeye neden olacaktır. Böyle bir kilitlenmenin çözülmesi ve yasama faaliyetinin sürdürülebilmesi için anayasalarda değişik yöntemlere yer verilmektedir ${ }^{69}$. Bu yöntemlerden bazılarının uygulanmas1, üst meclisin mutlak vetosuna rağmen bir kanun teklifinin kanunlaşması sonucunu

66 Ganghof, “A New Political System Model”, s. 266.

67 Bulmer, Bicameralism, s. 21.

68 Pierre-Étienne Vandamme/ Vincent Jacquet/ Christoph Niessen/ John Pitseys / Min Reuchamps, "Intercameral Relations in a Bicameral Elected and Sortition Legislature", 2018, 46(3), Politics \& Society, s. 387.

69 İki meclis arasında ortaya çıkan çatışmaların çözülmesi için kullanılan yöntemler; kanun teklifinin her iki meclis arasında gidip gelmesi (mekik sistemi), konferans komitelerinin kurulması, alt meclisin belli çoğunlukla almış olduğu kararın geçerli sayılması, iki meclisin ortak oturum düzenlemesi, referanduma başvurulması ve meclislerin feshedilerek yeni seçimlere gidilmesi şeklinde sıralanabilir. Bahsi geçen yöntemlerin, üst meclisin mutlak bir veto yetkisine sahip olup olmadığından bağımsız olarak, iki meclis arasında ortaya çıkan uyuşmazlıkları gidermek için kullanıldığını belirtmek gerekir. Örneğin, bir kanun teklifi üzerinde üst meclisin vetosu, alt meclisin kararıyla aşılabiliyorsa bu durumda üst meclisin mutlak bir veto yetkisine sahip olduğundan bahsedilemez. Ancak üst meclisin mutlak olmasa da yapmış olduğu veto, iki meclis arasında bir uyuşmazlık ortaya çıkarmış ve bu uyuşmazlık alt meclisin kararıyla aşılmıştır. İki meclis arasında ortaya çıkan çatışmaların çözülmesi için kullanılan yöntemler ile ilgili bkz. Bulmer, Bicameralism, s. 21-23; George Tsebelis/ Jeannette Money, Bicameralism, Cambridge University Press, 1997, s. 54-70. 
doğurabilmektedir. Örneğin, üst meclis tarafindan kabul edilmeyen bir kanun teklifi için referanduma gidilmesi veya her iki meclisin feshedilerek yeni seçimlerin yapılması, iki meclis arasındaki çatışmanın çözülmesini sağlayan yöntemler olarak anayasalarda düzenlenebilmektedir. Bu örneklerde, kanun teklifinin referandum sonucunda veya seçimlerin ardından oluşan yeni meclis tarafindan tekrar gündeme getirilerek kabul edilmesi, daha önce üst meclis tarafindan yapılan vetonun mutlak olma niteliğini ortadan kaldırmamaktadır.

Görüldüğü üzere üst meclisin mutlak veto yetkisine sahip olması, çeşitli yöntemlerle sınırlanabilse de ona kanun yapım sürecini kilitleyebilecek önemli bir güç sağlamaktadır. Bu nedenle, iki meclisli yasama organlarına sahip ülkeler anayasalarında, genellikle üst meclise ya mutlak veto yetkisi tanımamakta ya da bu yetkiyi anayasa değişikliğine ilişkin kanunlar gibi yalnızca belli alanlarda tanımaktadır ${ }^{70}$. İdeal bir yarı parlamenter sistemde ise üst meclisin mutlak veto yetkisine yalnızca bütçe kanunları bakımından istisna getirilmiştir. Ancak bu istisnanın, üst meclise önemli bir güç sağlayan mutlak veto yetkisini sınırlandırmak amacıyla getirildiğini söylemek mümkün görünmemektedir. Zira daha önce de belirtildiği gibi, yarı parlamenter sistemde hükümet, yasama organının bir bölümünün güvenine tabidir. İki meclisli yasama organları düşünüldüğünde, ideal bir yarı parlamenter sistemde hükümete güvensizlik oyu verme yetkisine alt meclis sahiptir. $\mathrm{Bu}$ yetkiye sahip olmayan üst meclise, fiili bir güvensizlik oyu şeklinde kullanılabilmesinden ötürü bütçe kanunları üzerinde mutlak veto yetkisi de tanınmamalıdır. Dolayısıyla üst meclisin bütçe kanunları bakımından mutlak veto yetkisine sahip olmaması, ideal bir yarı parlamenter sistemin kendi içinde tutarlılığını sağlamaya yönelik bir düşünce olarak değerlendirilebilir. Bütçe kanunları hariç tutulduğunda ise ideal bir yarı parlamenter sistemde üst meclise kanunlar üzerinde mutlak veto yetkisi tanınmasının, iki meclisin birbirlerini dengeleyen rollere sahip olmasını sağladığı ifade edilebilir. Böylelikle yasama ile yürütme organı arasındaki ilişkilerde alt meclis; yasama faaliyetinde ise üst meclis önemli bir rolü yerine getirmektedir.

Son olarak, diğer hükümet sistemi modelleri göz önünde bulundurulduğunda, özellikle parlamenter sisteme sahip ülkelerde üst meclisin kanunlar üzerinde mutlak veto yetkisine sahip olmasına rastlanıldığını belirtmek gerekir. Kanada, Hollanda ve Almanya gibi parlamenter sisteme

\footnotetext{
70 Bulmer, Bicameralism, s. 23.
} 
sahip ülkeler, üst meclislerine bu yetkiyi tanıyan ülkelerden birkaçıdır ${ }^{71}$. $\mathrm{Bu}$ yönüyle, ideal biçimiyle de olsa yarı parlamenter sistemde, parlamenter sistemde uygulama alanı bulabilen bir özelliğin benimsendiği görülmektedir.

\section{GANGHOF'A GÖRE YARI PARLAMENTER SISTEMIN UYGULAMASI: AVUSTRALYA VE JAPONYA ÖRNEKLERI}

Yarı parlamenter sistemi kurumsallaştıran Ganghof, bu sistemin özelliklerini taşıyan iki ülke olduğunu belirlemektedir: Avustralya ve Japonya. Bahsi geçen ülkelerde, Ganghof'un görüşleri doğrultusunda yarı parlamenter sistemin nasıl uygulandığ 1 ve ideal bir yarı parlamenter sisteme ne ölçüde yaklaşıldığı değerlendirilmelidir. Sağlıklı bir değerlendirme yapabilmek için yarı parlamenter sistemin ve ideal biçiminin yukarıda açıklanan özellikleri Tablo 1'de bir arada gösterilmektedir.

YASAMA

(Yasama organı doğrudan halk tarafindan seçilen iki bölümden oluşmaktadır. İdeal bir yarı parlamenter sistemde demokratik meşruiyeti yüksek olmak kaydiyla doğrudan halk tarafindan seçilme koşuluna esneklik getirilebilir.)

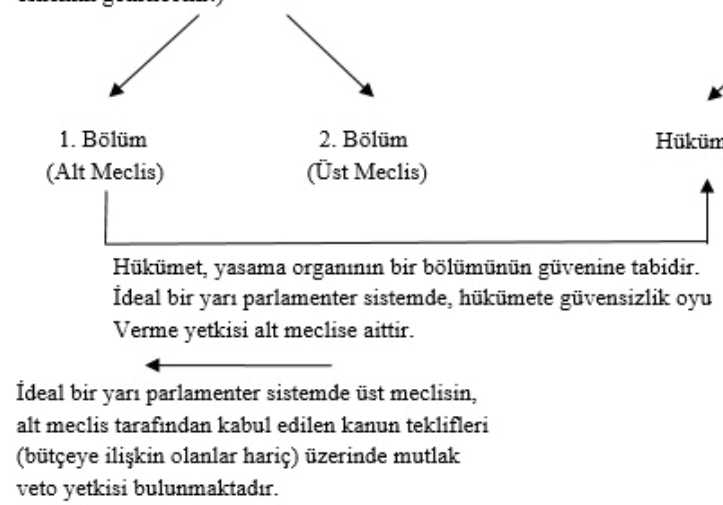

Tablo 1: Yarl Parlamenter Sistemin Genel Görünümiu

\section{YÜRÜTME}

(Yürütme organı ikili bir yapiya sahiptir. Bir tarafta başbakan ve bakanlardan oluşan hükümet; diğer tarafta devlet başkanı bulunmaktadır. Devlet başkanı halk tarafindan seçilmemelidir.)

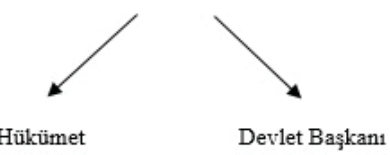

71 Bulmer, Bicameralism, s. 14.

860 Ankara Hacı Bayram Veli Üniversitesi Hukuk Fakültesi Dergisi C. XXV, Y. 2021, Sa. 2 
Tablo 1'de ifade edilen bilgiler doğrultusunda, Ganghof tarafından yarı parlamenter sisteme sahip olduğu kabul edilen Avustralya ve Japonya'da bu sistemin genel görünümü Tablo 2'de ele alınmaktadır.

\begin{tabular}{|l|c|c|}
\hline $\begin{array}{l}\text { Devlet başkanının halk } \\
\text { tarafından seçilmemesi }\end{array}$ & Avustralya & Japonya \\
\hline $\begin{array}{l}\text { Yasama organının doğrudan } \\
\text { halk tarafından seçilen iki } \\
\text { bölümden oluşması }\end{array}$ & Evet & Evet \\
\hline $\begin{array}{l}\text { Yürütme organının görevine } \\
\text { devam edebilmesinin, yasama } \\
\text { organının bir bölümünün (alt } \\
\text { meclisin) güvenine bağlanması }\end{array}$ & Evet & Evet \\
\hline $\begin{array}{l}\text { Kanun yapım sürecinde üst } \\
\text { meclisin mutlak veto yetkisine } \\
\text { sahip olması }\end{array}$ & Evet & Hayır \\
\hline $\begin{array}{l}\text { Bütçeye ilişkin kanunlarda üst } \\
\text { meclisin mutlak veto yetkisinin } \\
\text { bulunmaması }\end{array}$ & Hayır & Evet \\
\hline
\end{tabular}

Tablo 2: Avustralya ve Japonya'da Yarı Parlamenter Sistemin Genel Görünüm $\ddot{u}^{72}$

Tablo 2'nin ilk üç satırı, yarı parlamenter sistemin tanımlayıcı unsurlarını ifade etmektedir. Bu nedenle, yarı parlamenter sisteme sahip oldukları ifade edilen Avustralya ve Japonya'da bahsi geçen unsurların bulunmasını doğal karşılamak gerekir. Tablonun kalan kısmı ise ideal bir yarı parlamenter sistemde yer alması gereken unsurlarla ilgili olduğundan, her iki ülke açısından bazı farklılıklar ortaya çıkmaktadır.

Tablo 2'de yer alan hususlar üzerinde sirasiyla durulacak olursa, Avustralya ve Japonya'da devlet başkanlarının halk tarafından seçilmediği görülmektedir. İngiliz Milletler Topluluğunun bir parçası olan Avustralya'da

72 Ganghof, “A New Political System Model”, s. 265. 
İngiltere Kraliçesi devlet başkanı olarak tanınmaktadır. Ancak Kraliçe tarafından atanan Genel Vali, Kraliçeyi temsilen devlet başkanlığını yerine getirmektedir ${ }^{73}$. Japonya'da ise devlet başkanı olan İmparator, veraset kurallarına göre belirlenmektedir ${ }^{74}$.

Avustralya ve Japonya'da yasama organları Temsilciler Meclisi (alt meclis) ve Senatodan (üst meclis) oluşan iki meclisli bir yapıya sahiptir. Her iki ülkede de Temsilciler Meclisi ve Senato üyelerinin tamamı doğrudan halk tarafından seçilmektedir ${ }^{75}$. Bu noktada bahsi geçen ülkelerde, özellikle üst meclislerin tüm üyelerinin doğrudan halk tarafından seçildiğine dikkat çekmek gerekmektedir. Zira daha önce de belirtildiği gibi, üst meclislerin tüm üyelerinin halk tarafından seçilmesine sıklıkla rastlanmadığından, ideal bir yarı parlamenter sistem açısından yasama organının iki bölümünün eşit meşruluğuna vurgu yapılmaktadır. Bu kapsamda Ganghof, tamamı doğrudan halk tarafindan seçilmese de seçilme yöntemi açısından demokratik meşruluğa sahip üst meclislerin bulunduğu ülkelerin de yarı parlamenter olarak sınıflandırılmasına olumlu yaklaşmaktadır ${ }^{76}$. Ancak Ganghof'un kendi sınıflandırmasında, yarı parlamenter sistemin uygulama alanını genişleten bu yaklaşım yerine, yarı parlamenter sistemin tanımlayıcı unsurlarından hareket ettiği ve üst meclisin tüm üyelerinin doğrudan halk tarafından seçilmesi unsuruna bağl1 kaldığı görülmektedir ${ }^{77}$.

Avustralya ve Japonya'da hükümetin görevine devam etmesi, alt meclis konumunda olan Temsilciler Meclisinin desteğine bağlıdır. Temsilciler Meclisinin güveni, hükümetin görevini sürdürmesini sağlamaktadır ${ }^{78}$. Üst meclis konumundaki Senatoların ise böyle bir yetkisi bulunmamaktadır.

İdeal bir yarı parlamenter sistemde, kanun yapım sürecinde yer alması gereken üst meclisin mutlak veto yetkisine Avustralya'da rastlanmaktadır.

731901 Avustralya Anayasası m.2, 61.

741946 Japonya Anayasası m.1, 2.

75 Avustralya, Japonya ve diğer ülkelerin ulusal yasama organlarının yapılarıyla ilgili güncel ve ayrıntılı bilgiler için bkz. https://data.ipu.org/content/parline-global-data-nationalparliaments (erişim tarihi: 16.09.2020).

76 Ganghof, “A New Political System Model”, s. 265-266; Ganghof/ Eppner/ Pörschke, s. 227, dn. 3 .

77 Elgie, "On New Forms of Government", s. 245-246.

78 David Hamer, Can Responsible Government Survive in Australia?, Second Edition, The Department of the Senate, 2004, s. 113, 165. 1946 Japonya Anayasas1, hükümetin alt meclise karş1 sorumluluğunu açık bir biçimde düzenlemiştir (m.69). 
Avustralya Anayasasının 57. maddesine göre bir kanun teklifinin Temsilciler Meclisinde kabul edildikten sonra aynı şekilde Senato tarafindan da kabul edilmesi gerekmektedir. Temsilciler Meclisinin kabul ettiği kanun teklifinin Senato tarafından kabul edilmemesi veya bazı değişiklikler yapılarak kabul edilmesi halinde iki meclis arasında anlaşmazlık ortaya çıkmaktadır. Bu durumda üç aylık bir aradan sonra, Temsilciler Meclisi kanun teklifini aynı şekilde veya Senato tarafından yapılan değişikliklerle tekrar kabul ederse ve Senato yine bu teklifi kabul etmez veya bazı değişikliklerle kabul ederse, Genel Vali her iki meclisi aynı anda feshedebilir. Fesih sonucunda yapılan seçimlerle yenilenen meclisler arasında aynı kanun teklifi ile ilgili anlaşmazlık devam ediyorsa, her iki meclisin üyelerinin katıldığı ortak bir oturum düzenlenmektedir. Bu oturumda Senatonun kanun teklifi üzerindeki mutlak vetosunun etkinliğini kaybetmesi ve teklifin Temsilciler Meclisinin istediği biçimde kanunlaşması muhtemeldir. Zira Temsilciler Meclisinin, Senatoya göre daha fazla üyesi bulunmaktadır ${ }^{79}$.

Japonya'da ise Senato kanun yapım sürecinde mutlak veto yetkisine sahip değildir. Her ne kadar Japonya Anayasasının 59. maddesine göre Temsilciler Meclisinin kabul ettiği kanun teklifinin kanunlaşabilmesi, kural olarak Senatonun kabulüne bağlansa da Senato tarafından yapılan vetonun kanun yapım sürecini engellediğinden bahsetmek mümkün görünmemektedir. Zira kanun teklifi, Temsilciler Meclisinde kabul edildiği şekliyle Senatodan geçmezse yeniden Temsilciler Meclisinin önüne gelmekte ve Temsilciler Meclisi mevcut üyelerinin üçte ikisi ile tekrar kabul edilmesi halinde kanunlaşmaktadır.

İdeal bir yarı parlamenter sistemde, bütçeye ilişkin konularda çıkarılan kanunlar bakımından üst meclisin mutlak veto yetkisine sahip olmamas1 gerektiği yukarıda ifade edilmişti. Kanun yapım sürecinde üst meclise mutlak veto yetkisinin tanınmadığı Japonya'da bütçe kanunları bakımından da farklı bir durum söz konusu değildir. Japonya Senatosunun, bütçeye ilişkin konularda çıkarılan kanunlar üzerinde mutlak veto yetkisi bulunmamaktadır. Buna karşılık, Avustralya Senatosu sıradan kanunlar gibi bütçeye ilişkin konularda çıkarılan kanunlar bakımından da mutlak veto yetkisine sahiptir.

79 Ganghof, "A New Political System Model”, s. 266; Bulmer, Bicameralism, s. 25; Harry Evans, "The Role of the Australian Senate" in R.C. Tripathi (Ed.), Second Chambers; Bicameralism Today, Rajya Sabha Secretariat, 2002, s. 2. 
Yarı parlamenter sistemin tanımlayıcı unsurlarını barındıran Avustralya ve Japonya'nın, ideal bir yarı parlamenter sisteme ne ölçüde uygun olduğunu bu bilgiler doğrultusunda değerlendirmek gerekmektedir. Japonya, üst meclisin bütçe dışı konularda çıkarılan kanunlar üzerinde mutlak veto yetkisine sahip olmaması bakımından ideal bir yarı parlamenter sistemden uzaklaşmaktadır. Avustralya'da ise üst meclisin mutlak veto yetkisinin bütçe kanunları için de söz konusu olması, ideal yarı parlamenter sisteme uygun bir özellik değildir. Ayrıca Ganghof'a göre, üst meclisin mutlak vetosu halinde iki meclis arasındaki anlaşmazlık, alt meclisin etkin olduğu ortak bir oturumda çözülebiliyorsa yine ideal yarı parlamenter sisteme uygun bir görüntü ortaya çıkmamaktadır ${ }^{80}$. Bu son durum, daha önce bahsedildiği gibi, Avustralya'da bulunmaktadır. Avustralya'da üst meclisin kanun yapım sürecinde mutlak veto yetkisini kullanması üzerine ortaya çıkan iki meclis arasındaki anlaşmazlık, önce yeni seçimlere gidilerek sonrasında ise iki meclisin ortak oturumunda çözülebilmektedir. Ortak oturuma alt meclisin iradesinin hakim olması, üst meclisin sahip olduğu mutlak veto yetkisinin etkinliğini azaltmaktadır. Dolayısıyla gerek Avustralya gerekse de Japonya, Ganghof'un belirlediği yarı parlamenter sistemin ideal biçimine tam olarak uygun örnekler değildir ${ }^{81}$.

\section{SONUÇ}

Ganghof yarı parlamenter sistemi, yarı başkanlık sisteminden esinlenerek ancak bu sistemin tersi bir mantıkla oluşturmuştur. Yarı başkanlık sisteminde, ikili yapıya sahip olan yürütme organının yetki paylaşımı ve seçilme biçimi önemliyken; yarı parlamenter sistemde iki bölüme sahip olan yasama organının yetki paylaşımı ve seçilme biçimi öne çıkmaktadır. Yarı parlamenter sistemde iki meclisli yasama organları düşünüldüğünde, üst ve alt meclis doğrudan halk tarafindan seçilmekte ve hükümete güvensizlik oyu verme yetkisi yalnızca alt meclise tanınmaktadır. Buna karşılık ideal bir yarı parlamenter sistemde üst meclisin, kanun yapım sürecinde mutlak bir veto yetkisine sahip olması gerekmektedir.

Yarı parlamenter sistemde, yasama organı içinde özellikle de üst meclisin konumunun belirleyici olduğu görülmektedir. Zira üst meclisin hükümete güvensizlik oyu verme yetkisinin bulunmaması ve tüm üyelerinin doğrudan halk tarafindan seçilmesi koşullarının aynı anda bir ülkede bulunması oldukça zordur. Nitekim yalnızca Avustralya ve Japonya'nın bu koşullara uyduğu ve

\footnotetext{
80 Ganghof, “A New Political System Model”, s. 266; Ganghof/ Eppner/ Pörschke, s. 216.

81 Ganghof/ Eppner/ Pörschke, s. 216; Ganghof, “A New Political System Model”, s. 266.
} 
yarı parlamenter sisteme sahip olduğu Ganghof tarafindan kabul edilmektedir. Bununla birlikte söz konusu ülkeler, üst meclislerin kanun yapım sürecinde bütçe kanunlarını kapsayacak şekilde mutlak veto yetkisinin bulunması (Avustralya) veya mutlak veto yetkisinin tümüyle bulunmaması (Japonya) yönlerinden Ganghof'un tasarladığı ideal yarı parlamenter sistemden sapmaktadır.

Ganghof yarı parlamenter sistemi, ayrı bir hükümet sistemi modeli olarak sunmaktadır. Kanaatimizce, yarı parlamenter sistem tamamen ayr1 bir hükümet sistemi modeli olarak değerlendirilmemelidir. Yarı parlamenter sistemin tanımlayıcı unsurları göz önünde bulundurulduğunda, bu unsurların parlamenter sistem için de geçerli olduğu görülmektedir. Şöyle ki parlamenter sistemde tartışmalı olmakla birlikte, devlet başkanının halk tarafından seçilmesi mümkündür ancak esas olan halk tarafından seçilmeyen bir devlet başkanının varlığıdır. Diğer yandan, iki bölümden oluşan ve üyelerinin tamamı doğrudan halk tarafından seçilen bir yasama organı, diğer hükümet sistemi modelleri gibi parlamenter sistemde de bulunabilir. Son olarak, hükümetin görevine devam etmesinin, yasama organının güvenine bağlanması parlamenter sistemin temel bir özelliğidir. Hükümetin, yasama organının yalnızca bir bölümüne karşı sorumlu olduğu veya hükümete güvensizlik oyu verme yetkisinin, yasama organının yalnızca bir bölümüne tanındığ 1 bir sistemin parlamenter olarak nitelenmesine de bir engel bulunmamaktadır. Zira bu durumda da hükümetin yasama organına karşı sorumlu olması koşulu sağlanmış olmaktadır.

$\mathrm{Bu}$ açıklamalar doğrultusunda Ganghof tarafından ortaya konan yarı parlamenter sistemi, parlamenter sistem kapsamında değerlendirmek gerekmektedir. Yarı parlamenter sistem, parlamenter sistemin bir alt türü olarak ifade edilebilir. Bununla birlikte, ister ayrı bir hükümet sistemi modeli olarak isterse de parlamenter sistem kapsamında değerlendirilsin, Ganghof'un denge ve denetim bakımından etkili bir hükümet sistemi modeli ortaya koyduğunu kabul etmek gerekmektedir. Zira kanun yapım sürecinde belirleyici role sahip olan üst meclisin, hükümetin görevine devam etmesinde herhangi bir yetkisinin bulunmaması ve bu yetkinin alt meclise tanınması, yasama organının kendi içinde ve yürütme organıyla olan ilişkilerinde sınırlarını belirlemektedir. $\mathrm{Bu}$ yönüyle yarı parlamenter sistem, özel bir iki meclislilik örneği sunmaktadır. 


\section{KAYNAKÇA}

Bulmer E., Bicameralism, Second Edition, International IDEA ConstitutionBuilding Primer 2, 2017.

Bulmer E., Non-Executive Presidents in Parliamentary Democracies, Second Edition, International IDEA Constitution-Building Primer 6, 2017.

Carey J. M., "Presidential versus Parliamentary Government", in Claude Menard/ Mary M. Shirley (Eds.), Handbook of New Institutional Economics, Springer, 2005, s. 91-122.

Cheibub J. A., Presidentialism, Parliamentarism, and Democracy, Cambridge University Press, 2007.

Duverger M., "ANew Political System Model: Semi-Presidential Government", 1980, 8(2), European Journal of Political Research, s. 165-187.

Duverger M., "Reflections: The Political System of the European Union", 1997, 31(1), European Journal of Political Research, s. 137-146.

Elgie R., "On New Forms of Government”, 2018, 53(2), Australian Journal of Political Science, s. 241-247.

Elgie R., "The Classification of Democratic Regime Types: Conceptual Ambiguity and Contestable Assumptions", 1998, 33(2), European Journal of Political Research, s. 219-238.

Elgie R., "The Politics of Semi-Presidentialism" in Robert Elgie (Ed.), SemiPresidentialism in Europe, Oxford University Press, 1999, s. 1-21.

Elgie R., "The President of Ireland in Comparative Perspective", 2012, 27(4), Irish Political Studies, s. 502-521.

Epstein L. D., "Parliamentary Government", in David L. Sills (Ed.), International Encyclopedia of the Social Sciences, 11, Macmillian and Free Press, 1968, s. 419-425.

Evans H., "The Role of the Australian Senate" in R.C. Tripathi (Ed.), Second Chambers; Bicameralism Today, Rajya Sabha Secretariat, 2002, s. 1-7.

Fabbrini S., "Features and Implications of Semi-Parliamentarism: The Direct Election of Italian Mayors", 2001, 6(2), South European Society and Politics, s. 47-70. 
Ganghof S., "A New Political System Model: Semi-Parliamentary Government", 2018, 57(2), European Journal of Political Research, s. 261-281.

Ganghof S., "Bicameralism As a Form of Government (Or: Why Australia and Japan Do Not Have a Parliamentary System)", 2014, 67(3), Parliamentary Affairs, s. 647-663.

Ganghof S./ Eppner S./ Pörschke A., "Australian Bicameralism as SemiParliamentarism: Patterns of Majority Formation in 29 Democracies", 2018, 53(2), Australian Journal of Political Science, s. 211-233.

Hamer D., Can Responsible Government Survive in Australia?, Second Edition, The Department of the Senate, 2004.

https://data.ipu.org/content/parline-global-data-national-parliaments (Erişim tarihi: 16.09.2020).

Lijphart A., "Introduction", in Arend Lijphart (Ed.), Parliamentary versus Presidential Government, Oxford University Press, 1992, s. 1-27.

Lijphart A., Patterns of Democracy; Government Forms and Performance in Thirty-Six Countries, Second Edition, Yale University Press, 2012.

Linz J. J., "Presidential or Parliamentary Democracy: Does It Make a Difference?" in Juan J. Linz/ Arturo Valenzuela (Eds.), The Failure of Presidential Democracy, The Johns Hopkins University Press, 1994, s. 3-87.

MacDonald W., A New Constitution For A New America, B. W. Huebsch, 1921.

Müller W. C./ Bergman T./ Strøm K., "Parliamentary Democracy: Promise and Problems", in Wolfgang C. Müller/ Torbjörn Bergman/ Kaare Strøm (Eds.), Delegation and Accountability in Parliamentary Democracies, Oxford University Press, 2006, s. 3-32.

Onar E., İsrail'in Kendine Özgü Bir Hükümet Sisteminden Eskisine Geri Dönüşü, 72 Tasarım, 2003.

O’Neil P., "Presidential Power in Post-Communist Europe: The Hungarian Case in Comparative Perspective", 1993, 9(3), Journal of Communist Studies, s. 177-201. 
Özsoy Boyunsuz Ş., Başkanlı Parlamenter Sistem; Cumhurbaşkanının Halk Tarafından Seçildiği Parlamenter Hükümet Modeli ve Türkiye İçin Tavsiye Edilebilirliği, 2. Baskı, On İki Levha Yayınları, 2014.

Riggs, F. W., "The Survival of Presidentialism in America: Paraconstitutional Practice”, 1988, 9(4), International Political Science Review, s. 247-278.

Samuels D. J. / Shugart, M. S., Presidents, Parties, and Prime Ministers; How the Separation of Powers Affects Party Organization and Behavior, Cambridge University Press, 2010.

Sartori G., Karşılaştırmalı Anayasa Mühendisliği; Yapılar, Özendiriciler ve Sonuçlar Üzerine Bir İnceleme, Ergun Özbudun (Çev.), Yetkin Yayınları, 1997.

Shugart M. S., "Semi-Presidential Systems: Dual Executive and Mixed Authority Patterns", 2005, 3(3), French Politics, s. 323-351.

Shugart M. S., "Of Presidents and Parliaments", 1993, 2(1), East European Constitutional Review, s. 30-32.

Shugart M. S./ Carey J. M., Presidents and Assemblies; Constitutional Design and Electoral Dynamics, Cambridge University Press, 1992.

Tsebelis G./ Money J., Bicameralism, Cambridge University Press, 1997.

Uluşahin, N., Saf Hükümet Sistemleri Karşısında İki Başlı Yürütme Yapılanmas1, Yetkin Yayınları, 2007.

Vandamme P./ Jacquet V./ Niessen C./Pitseys J./ Reuchamps M, "Intercameral Relations in a Bicameral Elected and Sortition Legislature", 2018, 46(3), Politics \& Society, s. 381-400. 